\title{
Some critical factors in personal financial planning
}

\author{
P.W.C. de Wit \\ Department of Business Economics, University of Pretoria, Pretoria, 0001 Republic of South Africa
}

\begin{abstract}
The use of effective financial planning is often neglected by private individuals. In the inflationary environment of today the lack of financial planning can lead to financial disaster, especially when a person reaches his or her retirement age. This article reports the results of a study regarding financial planning by private individuals. It highlights the different levels of wealth obtained and some of the methods used in obtaining those levels of wealth. An effort is made to give advice to the individual in order to curb the statement so often heard: 'If I were a rich man'.

Privaat individue is soms geneig om nie van doeltreffende finansiële beplanning gebruik te maak nie. Dit bring mee dat talle mense wat hul aftree-ouderdom bereik, finansiële rampe beleef, veral weens die inflasionistiese toestande wat deesdae heers. Hierdie artikel doen verslag oor 'n studie wat in verband met finansiële beplanning deur private individue onderneem is. Dit beklemtoon die onderskeie vlakke van rykdom wat behaal is en die metodes wat aangewend is om dit te behaal. Daar word gepoog om finansiële advies aan die individu te verskaf, sodat die stelling: 'As ek maar 'n ryk man was' nie so dikwels gehoor word nie.
\end{abstract}

\section{Introduction}

Inflation is undoubtedly one of every citizen of the Republic of South Africa's worst enemies if not the worst. People so often try to save during their lives and when they retire they find that they can hardly exist on their savings. This is usually the result of inflation.

Another factor that normally ends up in financial disaster is when a person enjoys a 'good life' by living well above his means (Hurley, 1981: 3). Should a person prefer a simpler life style by saving more money and by investing in more profitable ventures, he or she will stand a better chance to live better when they retire.

- Personal financial planning usually starts with an appraisal of a person's strengths and weaknesses (Hurley, 1981: 4). A long-term financial goal must be set with these strengths and weaknesses as base. This can only lead to eventual financial independence (Tagtmeier, 1985: 89) provided a financial setback like the burning down of an uninsured house, does not occur. Typical financial objectives can be to (Gobeil, 1987: 31): - provide financial security for the family;

- provide money for children to attend college or university;

- provide funds to purchase a new house;

- enable a family to maintain a current standard of living, should a spouse die.

Ward \& Niendorf (1978: 458-459) identified four points in a person's life cycle where he or she experiences transition and change. These points are:

- the reaching of a person's legal majority when he or she must start supporting themselves. They may be students but they will have the responsibility to budget their expenses in accordance with their income;

- the decision to marry which normally brings about some drastic changes in a person's financial goals and spending patterns. Large debts can be incurred when the newly weds buy their furniture and even their first house. The sources of family income may become more as the wife starts working and it will become less when the wife must stop working to look after the children;

- when a spouse dies or when a couple gets divorced. Both of these cases bring about a drastic change in the household's income and require important decisions regarding the future of the household. An example of this is when small children are involved. Death or divorce will require important decisions regarding their educational and career matters;

- when a person decides to retire. This is usually the time when a couple changes home or relocates and when it is time to do some serious estate and tax planning. It usually brings about an important change in income.

\section{Objectives of the study}

Herbert Spiro (1978: 4) gave a descriptive definition of personal financial planning. He reckoned that personal financial planning "consists of initiating or validating a financial course of action based on the forecasts developed' by a person for his or her expected income stream

Personal financial planning encloses the following:

- the setting of a long-term goal in accordance with a person's strengths and weaknesses (Hurley, 1981: 4);

- the maximizing of a person's financial preferences should it be material acquisitions, long-term wealth or whatever the case might be;

- the introduction of a proper record-keeping system; and

- the drafting of monthly and annual budgets.

The four points stated above are used as the basis of the study. The objectives are to ascertain the extent to which people make use of the stated financial planning methods.

\section{Methodology}

A questionnaire consisting of 31 questions was mailed to 400 private individuals in Pretoria. The telephone directory of the city served as the sampling frame to the 
study. The response rate was $20,5 \%$ or 82 usable questionnaires. Some very favourable remarks came from the respondents.

\section{Results of the study}

Table 1 gives an overall insight into the answers that can be expressed in quantitative terms.

Table 1 emphasizes that $74 \%$ of the respondents are satisfied that they will be able to retire with financial peace of mind. These results immediately bought the writer to the question, namely what must the total net assets of a person be in order to retire with financial peace of mind? The net assets of the respondents older than 50 years of age were taken as shown in Table 2 . This age was selected as a person over this age is slowly but surely running out of time in acquiring more assets unless there is an inheritance waiting.

Table 2 indicates that all the respondents that indicated that they will be able to retire with financial peace of mind have built up quite a substantial sum of money through the years except for respondents numbers 1,12 and 23 . There is a notable difference in perception as far as the obtaining of financial success is concerned. Respondent number 1 thinks he has obtained financial success whilst he only has assets to the amount of R45 724. Respondent number 24 reckons he has not reached financial success although he has total net assets of R444 000 .

The unsatisfied $36 \%$ in Table 1 give the following steps that they intend taking in order to rectify the situation as shown in Table 3 .

It is rather shocking to note that $47,6 \%$ of the unsatisfied respondents intend to do nothing about their problems. Thirty per cent $(30 \%)$ of these respondents intending to do nothing are over 50 years of age and may feel that it is too late to do anything significant about it. Ten to fifteen years is a short period available for building a substantial asset value.

A number of factors that may have contributed to the financial success or failure of respondents were identified and stated in the questionnaires. These factors are stated in Figure 1 in accordance to the regularity in which they appeared.

Table 1 Overall results of questions asked. Responses $(n)=82$

\begin{tabular}{lcccc}
\hline & $\begin{array}{c}\text { Yes } \\
\%\end{array}$ & $\begin{array}{c}\text { No } \\
\%\end{array}$ & $\begin{array}{c}\text { Male } \\
\%\end{array}$ & $\begin{array}{c}\text { Female } \\
\text { Description }\end{array}$ \\
\hline $\begin{array}{l}\text { People who can retire with financial } \\
\text { peace of mind }\end{array}$ & 74 & 26 & & \\
Will handle financial matters the & & & & \\
same way should they have their & & & & \\
lives over again & 60 & 40 & & \\
Married & 84 & 16 & & \\
Male gender & & & 87 & 13 \\
Income tax & & & 63 & 37 \\
\hline
\end{tabular}

Table 2 Net assets of respondents older than 50 years

\begin{tabular}{|c|c|c|c|c|c|c|}
\hline$n$ & $\begin{array}{l}\text { Age } \\
\text { years }\end{array}$ & $\begin{array}{l}\text { Peace of } \\
\text { mind }\end{array}$ & Success & Assets & Liabilities & Insurance \\
\hline 1 & 82 & Yes & Yes & 45724 & 0 & 0 \\
\hline 2 & 75 & Yes & Yes & 285000 & 0 & 0 \\
\hline 3 & 74 & Yes & Yes & 181016 & & 40000 \\
\hline 4 & 69 & No & Yes & 315000 & & 48000 \\
\hline 5 & 69 & Yes & Yes & 6000 & 0 & 4000 \\
\hline 6 & 69 & Yes & Yes & 272000 & 0 & 2000 \\
\hline 7 & 66 & Yes & Yes & 558000 & 0 & 50000 \\
\hline 8 & 65 & Yes & Yes & 817000 & 0 & 54000 \\
\hline 9 & 64 & Yes & Yes & 46000 & 0 & 130000 \\
\hline 10 & 64 & Yes & Yes & 320000 & 0 & \\
\hline 11 & 63 & No & Yes & 223500 & 38000 & 100000 \\
\hline 12 & 63 & Yes & Yes & 68000 & 3000 & \\
\hline 13 & 62 & Yes & Yes & 275000 & & 10000 \\
\hline 14 & 60 & No & Yes & 500000 & 0 & \\
\hline 15 & 59 & Yes & Yes & 323000 & 2000 & 100000 \\
\hline 16 & 59 & Yes & Yes & 187000 & 15526 & 189300 \\
\hline 17 & 56 & Yes & Yes & 288000 & 1400 & 52000 \\
\hline 18 & 56 & Yes & Yes & 230000 & 15000 & 250000 \\
\hline 19 & 56 & No & Yes & 218000 & 6600 & 500000 \\
\hline 20 & 54 & No & Yes & 262500 & 43000 & 250000 \\
\hline 21 & 54 & Yes & Yes & 500000 & 33000 & 700000 \\
\hline 22 & 53 & No & Yes & 543000 & 144000 & 110000 \\
\hline 23 & 53 & Yes & Yes & 158000 & 0 & \\
\hline 24 & 53 & Yes & No & 209000 & 15000 & 250000 \\
\hline 25 & 52 & Yes & Yes & 304000 & 6000 & 20000 \\
\hline
\end{tabular}

Table 3 Steps intended to rectify poor financial status $(n=21)$

\begin{tabular}{lr}
\hline & $\%$ \\
Intend doing nothing & 47,6 \\
Buy annuities and take out insurance & 19,0 \\
Save and invest more money & 19,0 \\
Try to take on part-time work & 9,5 \\
Intend to inherit money & 4,9 \\
\cline { 2 - 2 } & 100,0 \\
\hline
\end{tabular}

The importance of proper financial planning is very clear as indicated in Figure 1. The contributions of taxes, low salaries, and high inflation to financial failures are also evident. Table 1 indicates that $63 \%$ of the respondents considered the saving on income tax when they decided where to invest their money. Weiner stated that people must always try to save on taxes and do their investments for the greatest tax advantage (Weiner, 1986: 43).

It must be emphasized that the reasons that were given for financial failure cannot all be the result of poor financial planning. High cost of living, exorbitant taxes, low salaries, and inflation can be attributed to Third World developing pains.

The successful respondents were asked to identify 


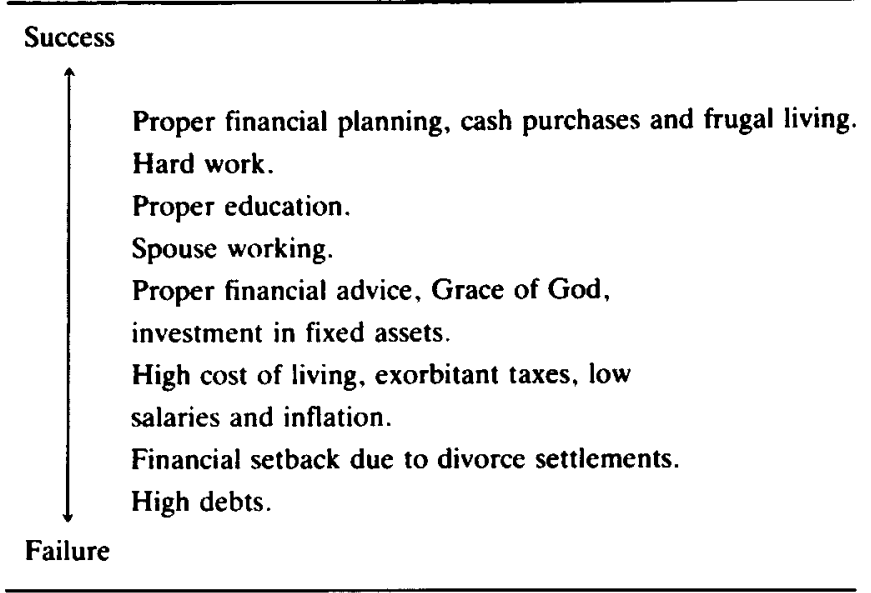

Figure 1 Factors that contributed to financial success/failure

$\begin{array}{ll}\text { More frequently mentioned } & \\ & \text { Accountant/Auditor/Bookkeeper. } \\ & \text { Bank manager. } \\ & \text { Insurance broker. } \\ & \text { Friends. } \\ & \text { Share broker. } \\ & \text { Financial publications. } \\ & \text { Lawyer. } \\ \text { Less frequently mentioned } & \end{array}$

Figure 2 Financial advisors used by successful respondents

More frequently mentioned

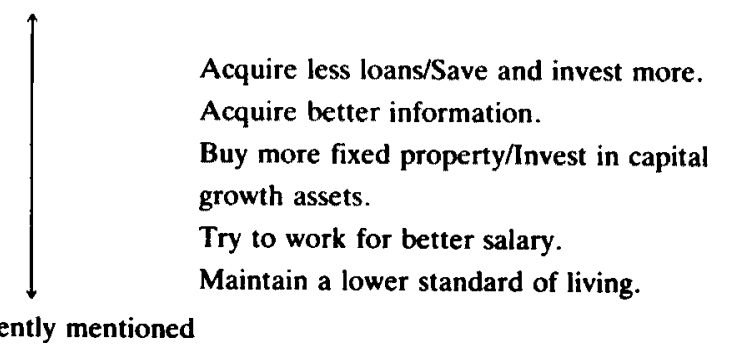

Figure 3 Steps in handling financial affairs

their financial advisors that helped them in reaching their financial goals. Figure 2 shows these responses in order of frequency.

Figure 2 proves that most of the respondents make use of advisors with experience in accountancy and investments. It actually seems strange that some people prefer their friends' advice to those of share brokers who have an in-depth experience in investments.

Respondents were also asked if they would handle their financial matters in the same way, should they have their lives all over again. Table 1 indicates that $40 \%$ of the respondents will not handle their financial matters in the same way. Figure 3 shows the steps that will be taken should they have another chance of making a success.

The influence of inflation manifests itself in Figure 3. People want to limit their loans and want to save and invest more. The fact that they want to invest in capital growth assets shows that they do not get a real return on other investments. This is due to inflation. Rudie stated that conservative investors with modest expectations and a long-term view are likely to obtain a much better performance from their investments than those who invest for quick short-term profits (Rudie, 1985: 106).

Most of the respondents $(97,5 \%)$ have a reasonable knowledge regarding their monthly expenses. They budget for their monthly income and expenses but the existence of long-term budgets for investments could not be ascertained from the answers.

Table 4 shows the percentage of respondents keeping proper records of their transactions. The conclusion can be made that the current difficult financial era that we live in, necessitates proper keeping of records. Bank accounts and income tax documentation are high on the list. Much of the record keeping of medical expenses is also done for income tax purposes.

\section{Conclusions}

The following conclusions arise from this study:

- The respondents do not have the same criteria regarding their assessment of financial success. Some have relatively little assets and they feel that they have achieved financial success. Others are very rich but are still not satisfied with their financial achievement as can be seen in Table 2 .

- Most of the respondents (74\%) are satisfied that they will one day retire with financial peace of mind. Those who are not satisfied know exactly what to do to rectify this situation as can be seen in Figure 1.

- All the respondents know exactly which factors contributed to their financial success or failure. They all know how they would handle their financial affairs, should they have their lives all over again (Figure 3).

- Accountants, auditors, bookkeepers, bank managers, and insurance brokers are more often used as advisors by respondents whom are satisfied with their financial position (Figure 2). The unsatisfied respondents also use financial advisors, but it cannot be concluded that their dissatisfaction is due to the advisors.

Table 4 Keeping of records by respondents

\begin{tabular}{lc}
\hline & $\%$ \\
\hline Bank accounts & 93,9 \\
Income tax & 85,3 \\
Insurance & 82,9 \\
Medical expenses & 85,3 \\
Other monthly expenses & 12,1 \\
Expenses pertaining other income & 3,7 \\
Loans & 3,6 \\
\hline
\end{tabular}


- Most of the respondents keep proper records of their bank accounts, income tax, and insurance matters (Table 4). This is very encouraging as far as financial planning is concerned.

- Most of the respondents seem to have their financial matters well under control.

\section{References}

Gobell, D.R. 1986. Expanding to meet the demand for personal financial planning. CA Magazine, April, 30-36.

Hurley, G.E. 1981. Personal money management. Englewood
Cliffs, New Jersey: Prentice Hall, Inc., 2nd edition. Rudie, M.J. 1985. You choose: income or growth. Restaurant Bus., November, Vol. 84, 106.

Spiro, H.T. 1978. Financial planning for the independent professional. New York: John Wiley \& Sons.

Tagtmeier, G. 1985. Helping employees with personal financial planning. Pers. Admin., October 1985, 87-91.

Ward, D.J. \& Niendorf, R.M. 1978. Consumer finance: the consumer experience. Georgetown: Richard D. Irwin, Inc.

Weiner, G.J. 1986. Money management for two-income couples. Supervis. Manage.,. February, vol. 31, 42-43. 